\title{
Vitamin A and immune function
}

\author{
B Y CLIVE E. WEST 1 , JAN H. W. M. ROMBOUT ${ }^{2}$, \\ AKKE J. VAN DER ZIJPP 3 AND S. REINDER SIJTSMA A $^{1,2,3}$ \\ Departments of ${ }^{1}$ Human Nutrition, ${ }^{2}$ Experimental Animal Morphology and Cell Biology and \\ ${ }^{3}$ Animal Husbandry, Wageningen Agricultural University, Wageningen, The Netherlands
}

Most evidence for a role of vitamin A in the immune defence system of humans comes from studies of infants and children in developing countries where vitamin A deficiency is often a serious problem. There it is associated with increased susceptibility to infection and to increased rates of morbidity and mortality. However, in the future, it can be expected that more studies will be carried out in developed countries where the observed effects of abnormal vitamin A status on immunity are likely to be subtle with marginal deficiency possibly contributing to increased prevalence and severity of non-infectious diseases with immune involvement such as cancer. Of course, it may well be that in affluent countries, intake and status of carotenoids are more important determinants of immune variables than those of retinol because of differences in their relative contribution to intake. In developing countries such as Tanzania, children receive less than $30 \%$ of their vitamin A from retinol (Pepping et al. 1989) while in Western countries such as the Netherlands, the situation is reversed with more than $60 \%$ of the vitamin $A$ being derived from retinol (Stiggelbout $e t$ al. 1989). This gives credence to a possible role of $\beta$-carotene as a protective factor for cancer (Peto et al. 1981) and may explain the different emphasis in the paper of Bendich (1991) in the present symposium and the present paper, which concentrates on the role of the immune response in relation to infection with particular emphasis on the problems of children in developing countries. Our knowledge in this area is supported by results obtained from studies in experimental animals.

\section{VITAMIN A DEFICIENCY, XEROPHTHALMIA, MORBIDITY AND MORTALITY}

For many years, the problem of vitamin A deficiency in developing countries emphasized the increased risk of xerophthalmia which includes all ocular manifestations of vitamin A deficiency (Oomen et al. 1964), although it has long been realized that vitamin A plays an important role in combating infection and was often referred to as the anti-infection vitamin. Over 60 years ago, Green \& Mellanby (1928) showed that when animals are brought up on a diet deficient in vitamin A, practically all die with some infective or pyrogenic lesions. In control animals receiving vitamin $A$, these lesions were absent. The earlier work on vitamin A and infection has been reviewed by Moore (1957) and by Schrimshaw et al. (1968). More recently, the importance of vitamin A deficiency in determining rates of morbidity and mortality has been highlighted by the work of Sommer et al. $(1983,1984,1986,1987)$ in Indonesia. The mortality rate among children with mild xerophthalmia (night blindness and Bitot's spots) was reported to be on average four times higher than that of children without xerophthalmia (Sommer et al. 1983). Using the same set of data, it was shown that children with mild vitamin A deficiency developed respiratory disease twice and diarrhoea three times as frequently as non-xerophthalmic controls (Sommer et al. 1984). Subsequently, the reverse of this 
relationship was found as children with respiratory disease or diarrhoea, or both, were found to be at an increased risk of developing xerophthalmia (Sommer et al. 1987). Studies by other groups have also shown a relationship between mild signs of vitamin A deficiency and childhood morbidity. In India, over 1500 preschool urban children were followed weekly for morbidity from 12 to 18 months. Examination for mild xerophthalmia (night blindness and Bitot's spots) was done initially and at 6 and 12 months (Milton et al. 1987). Children with mild xerophthalmia at the start of a 6-month interval developed respiratory disease in the interval twice as often as children with normal eyes at the start of the interval. Unlike in the Indonesian studies, no association was found between mild xerophthalmia and incidence of diarrhoea.

The hypothesis that vitamin A deficiency increases the rate of mortality was tested in a prospective study in which children, aged 12-71 months, in 450 villages in Aceh in North Sumatra in Indonesia were randomly assigned to either participate in a vitamin A supplementation scheme or to serve for 1 year as controls (Sommer et al. 1986). Mortality in the control villages was $49 \%$ greater than in the 229 villages where supplements were given. There have been quite a number of criticisms of this work (Gopalan, 1986; Anonymous, 1987) but studies are under way in a number of countries such as Nepal, Ethiopia and Ghana with designs which hopefully will overcome some of the earlier criticisms.

\section{INTERACTION BETWEEN VITAMIN A STATUS AND INFECTION}

In order to examine the underlying mechanisms of the interaction between vitamin $A$ deficiency and infection, vitamin A-deficient animals have been challenged with parasites (Krishnan et al. 1976; Darip et al. 1979); bacteria (Cohen \& Elin, 1974; Ongsakul et al. 1985) and viruses (Squibb \& Veros, 1961; Bang et al. 1972, 1973, 1975; Nauss \& Newberne, 1985; Nauss et al. 1985; Davis \& Sell, 1989). Many of the experimental models have used severely vitamin A-deficient animals in which it has been difficult to separate the effects of vitamin deficiency from those of more generalized protein-energy malnutrition. Therefore we have developed an animal model, based on chickens with marginal vitamin A deficiency and infected with Newcastle disease virus (Sijtsma et al. $1989 a, b)$ as this virus and the disease process associated with it have many characteristics in common with measles. Infection with measles is often associated with vitamin A deficiency in developing countries particularly in Africa (Inua et al. 1983). With this model (Fig. 1), 1-d-old chickens with limited vitamin A reserves, the progeny of marginally vitamin A-deficient hens, were fed on purified diets containing either marginal (120 retinol equivalents $/ \mathrm{kg}$ feed, $a d$ lib.) or adequate ( 1200 retinol equivalents/ $\mathrm{kg}$ feed, ad lib, or pair-fed) levels of vitamin A for a period of 10 weeks. At 4 weeks of age, half the chickens in each group were infected intraocularly with the mildly pathogenic La Sota strain of Newcastle disease virus. Infection with Newcastle disease resulted in increased rates of morbidity in the marginally-vitamin-A-deficient chickens, compared with their non-deficient infected counterparts. Moreover, within 1 week of infection, plasma retinol concentrations in the infected marginally-vitamin-A-deficient chickens showed a significant and persistent decrease compared with their non-infected counterparts fed on the same diet. Thus, infection with Newcastle disease virus exacerbates existing marginal vitamin A status and any effect of vitamin A deficiency on the immune system. 
A natural experiment in humans was observed by Campos et al. (1987). In Brazil, the vitamin A status of a group of children was determined by means of the relative dose-response method immediately before giving a massive oral dose of $60 \mathrm{mg}$ vitamin A. About $90 \mathrm{~d}$ after the start of the study, there was an epidemic of chicken pox. At $180 \mathrm{~d}$ post supplementation, $74 \%$ of children who had been infected were regarded as having depleted liver reserves of vitamin $\mathrm{A}$ as measured by the relative dose-response method in contrast to only $10 \%$ who had not been infected.

\section{HOST RESISTANCE: NON-SPECIFIC MECHANISMS}

Increased prevalence and severity of infections of the respiratory and gastrointestinal tracts which are not the primary causes of increased morbidity and mortality in children result from decreased host resistance. Many infections begin with local invasion of an epithelial surface. It is, therefore, important that the integrity of mucosal tissues is maintained with healthy epithelial cells.

Wolbach \& Howe (1925) showed that in vitamin A deficiency, mucus-producing epithelial cells were replaced by keratin-producing cells. These changes are seen particularly in the mucosa of the respiratory, gastrointestinal and genito-urinary tracts, in the conjunctival-corneal epithelium, and the lining of the taste buds. In cellular differentiation, specific depression of the genome occurs as characterized by the disappearance of proteins specific for the undifferentiated state and appearance of other specific proteins. There are a number of hypotheses proposed to explain the role of retinoids in cellular differentiation. Omori \& Chytil (1982) proposed that gene expression is controlled by retinoids while Wolf (1984) suggests that retinoids are involved in the synthesis of specific glycoproteins which influence gene expression particularly is compromised in vitamin A deficiency. Glycoproteins (Kornfield \& Kornfield, 1980) are also very important as components of surfaces of epithelial cells and of epithelial mucin. In vitamin A deficiency, the number of goblet cells in epithelial tissues such as of the duodenum (Ahmed et al. 1990) and conjunctiva (Hatchell \& Sommer, 1984) are also reduced. That vitamin $A$ is involved in the integrity and functioning of epithelial tissue has been demonstrated in a randomized double-blind trial of very-low-birth-weight neonates (Shenai et al. 1987). In this study, vitamin A supplementation was found to decrease the proportion of children developing bronchopulmonary dysplasia and the need for intensive care and supplemental oxygen.

After entering the body via epithelial surfaces, microbes spread to other tissues. The spread is facilitated by the circulatory system and hindered by macrophages and monocytes (Smith \& Sweet, 1984). Increased microbicidal capacity of macrophages in response to infection is largely non-specific since activated macrophages arising in response to infection with one micro-organism also show increased activity against other micro-organisms (Mogensen, 1979). Most of our knowledge in this area comes from studies in animals.

We have examined the effect of vitamin A deficiency on the activity of peritoneal macrophages in our chicken-Newcastle disease virus model (Sijtsma et al. 1991a). As described previously, chickens were fed on diets containing either marginal or adequate levels of vitamin A. At 4 weeks of age, half the chickens in each group were infected with the La Sota strain of Newcastle disease virus and 11 or $12 \mathrm{~d}$ later, peritoneal macrophages were isolated. The activity of macrophages against micro-organisms can be 


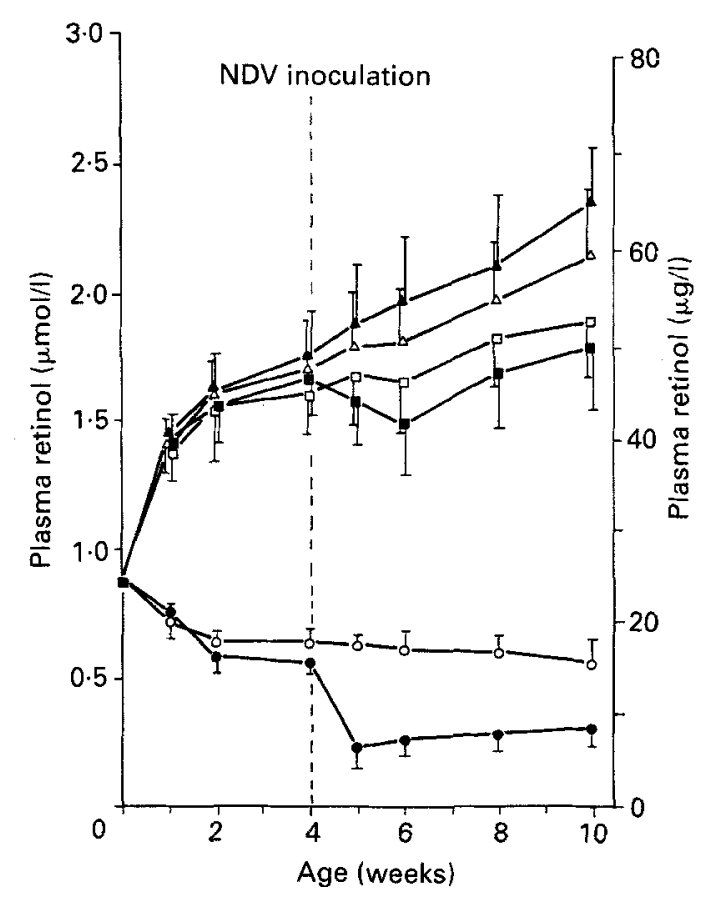

Fig. 1. Effect of Newcastle disease virus (NDV) infection $\left(\mathrm{I}^{+}\right)$on plasma retinol concentration in chickens fed from hatching diets containing marginal $\left(\mathrm{A}^{-}\right)$or adequate $\left(\mathrm{A}^{+}\right)$amounts of vitamin $\mathrm{A}$. Values are means and $1 \mathrm{SD}$ represented by vertical bars $(n 11-15)$. (O), $\mathrm{A}^{-}($ad lib. $) \mathrm{I}^{-} ;(\mathbf{O}), \mathrm{A}^{-}($ad lib. $) \mathrm{I}^{+} ;(\square), \mathrm{A}^{+}($pair $) \mathrm{I}^{-} ;(\mathbf{D})$, $\mathrm{A}^{+}$(pair) $\mathrm{I}^{+} ;(\Delta), \mathrm{A}^{+}($ad lib. $) \mathrm{I}^{-} ;(\mathbf{\Delta}), \mathrm{A}^{+}($ad lib. $) \mathrm{I}^{+} ; \mathrm{I}^{-}$, non-infected; ad lib., ad lib.-fed; pair, pair-fed.

divided into an attachment and ingestion phase (phagocytosis), which was assessed by counting the uptake of fluorescein isothiocyanate-labelled yeast cells, and an $\mathrm{O}_{2}$ dependent killing phase, which was assessed by measuring the reduction of nitroblue tetrazolium (NBT). Vitamin A deficiency tended to reduce phagocytosis but not significantly in peritoneal macrophages isolated from both infected and non-infected chickens as shown in Table 1 . These results are in line with those from studies with rats and mice where vitamin $\mathrm{A}$ has been demonstrated to stimulate clearance from the circulation by phagocytes after challenge with different types of bacteria and fungi (Cohen \& Elin, 1974; Ongsakul et al. 1985). As far as NBT reduction is concerned, the effects observed were more pronounced than that on phagocytosis (Table 2) with vitamin A deficiency producing significant lowering in NBT reduction in peritoneal macrophages isolated both from non-infected and infected chickens. The effect in infected chickens was only seen after additional stimulation in vitro with zymosan A particles isolated from yeast, suggesting that differences in NBT reduction could be attributed partially to the decrease in uptake. In a study in India, no differences were found between children with serum retinol levels above or below $200 \mu \mathrm{g} / \mathrm{l}$ in either phagocytic activity or $\mathrm{O}_{2-}$ dependent killing (Bhaskaram et al. 1989b). However, it may well be that the differences in serum retinol levels did not reflect differences in vitamin A status as represented by liver stores. 
Table 1. Vitamin A deficiency and Newcastle disease virus (NDV) infection in chickens: effect on phagocytosis of yeast cells by peritoneal macrophages (PM)

(Values are means with their standard errors for six to eight birds per group, and are expressed on basis of phagocytosing peritoneal macrophages)

\begin{tabular}{ccc}
\hline & $\begin{array}{c}\text { Phagocytic activity } \\
\text { (yeast cells ingested/PM) }\end{array}$ \\
\cline { 2 - 3 } & Mean & SE \\
\hline Non-infected chickens & & $0 \cdot 3$ \\
Vitamin A-adequate & $3 \cdot 7^{\mathrm{a}}$ & $0 \cdot 3$ \\
Vitamin A-deficient & $3 \cdot 4^{\mathrm{a}}$ & \\
NDV-infected chickens & & $0 \cdot 2$ \\
Vitamin A-adequate & $4 \cdot 6^{\mathrm{b}}$ & $0 \cdot 3$ \\
Vitamin A-deficient & $3 \cdot 8^{\mathrm{ab}}$ & 0.3 \\
\hline
\end{tabular}

a,b Values in a column with unlike superscript letters were significantly different (Tukey): $P<0 \cdot 05$.

Table 2. Vitamin A deficiency and Newcastle disease virus (NDV) infection in chickens: effect on nitroblue tetrazolium (NBT) reduction capacity of peritoneal macrophages as an estimate of oxygen-dependent killing capacity

(Values are means with their standard errors for seven to eight birds per group)

\begin{tabular}{|c|c|c|c|c|}
\hline & \multicolumn{4}{|c|}{ NBT reduction (absorbance/mg protein) } \\
\hline & \multicolumn{2}{|c|}{ Without zymosan A } & \multicolumn{2}{|c|}{ With zymosan A } \\
\hline & Mean & SE & Mean & SE \\
\hline \multicolumn{5}{|l|}{ Non-infected chickens } \\
\hline Vitamin A-adequate & $11 \cdot 6^{\mathrm{a}}$ & $1 \cdot 1$ & $32 \cdot 9^{a}$ & 1.6 \\
\hline Vitamin A-deficient & $7 \cdot 0^{b}$ & $1 \cdot 2$ & $20 \cdot 9 \mathrm{~b}$ & 1.8 \\
\hline \multicolumn{5}{|l|}{ NDV-infected chickens } \\
\hline Vitamin A-adequate & $14 \cdot 9^{\mathrm{a}}$ & $2 \cdot 1$ & $41 \cdot 8^{c}$ & $3 \cdot 6$ \\
\hline Vitamin A-deficient & $13 \cdot 1^{\mathrm{a}}$ & 1.6 & $26 \cdot 2^{\mathrm{ab}}$ & $2 \cdot 2$ \\
\hline
\end{tabular}

a,b,c Values in a column with unlike superscript letters were significantly different (Tukey): $P<0 \cdot 05$.

There is an inter-relationship between the function of 'non-specific' and 'specific' aspects of the immune system. On the one hand, in addition to the effects attributable to vitamin A deficiency, there was activation of the macrophages 11 and $12 \mathrm{~d}$ after virus inoculation which is indicative of an indirect effect of Newcastle virus on the cells possibly mediated by T-cell-derived lymphokines. On the other hand, macrophagederived monokines or macrophages themselves are also essential prerequisites for initiation and amplification of many immune responses. It may well be that the vitamin $A$ deficiency-induced impairment of humoral and cell-mediated immune responses discussed later could be, at least in part, the consequence of such disturbed macrophage function.

In addition to phagocytic cells, anti-viral substances such as the enzyme lysozyme, transferrins, precipitins, natural cytotoxins, and complement play a crucial role in 
Table 3. Vitamin A deficiency and Newcastle disease virus (NDV) infection in chickens: effect on lymphoid organ weights

(Values are means with their standard errors for six to eight birds per group)

\begin{tabular}{|c|c|c|c|c|c|c|}
\hline & \multicolumn{6}{|c|}{ Organ wt (g) } \\
\hline & \multicolumn{2}{|c|}{ Bursa } & \multicolumn{2}{|c|}{ Thymus } & \multicolumn{2}{|c|}{ Spleen } \\
\hline & Mean & $\mathrm{SE}$ & Mean & $\mathrm{SE}$ & Mean & $\mathrm{SE}$ \\
\hline \multicolumn{7}{|l|}{ Non-infected chickens } \\
\hline Vitamin A-adequate & $1 \cdot 84^{\mathrm{a}}$ & $0 \cdot 23$ & $1.75^{\mathrm{a}}$ & 0.47 & $0.90^{\mathrm{a}}$ & $0 \cdot 23$ \\
\hline Vitamin A-deficient & $1 \cdot 46^{\mathrm{bc}}$ & $0 \cdot 22$ & $1.55^{\mathrm{ab}}$ & $0 \cdot 21$ & $0 \cdot 81^{\text {a }}$ & $0 \cdot 21$ \\
\hline \multicolumn{7}{|l|}{ NDV-infected chickens } \\
\hline Vitamin A-adequate & $1.67^{\mathrm{ac}}$ & $0 \cdot 19$ & $1.85^{\mathrm{a}}$ & $0 \cdot 27$ & $1.06^{\mathrm{a}}$ & 0.22 \\
\hline Vitamin A-deficient & $1 \cdot 24^{\mathrm{b}}$ & $0 \cdot 16$ & $1 \cdot 31^{\mathrm{b}}$ & 0.26 & $0.90^{\mathrm{a}}$ & 0.22 \\
\hline
\end{tabular}

a,b,c Values in a column with unlike superscript letters were significantly different (Tukey): $P<0 \cdot 05$.

preventing the spread of infections. Lysozyme is a glycoprotein dependent on vitamin A for its synthesis. This dependence on vitamin A was borne out in a study in children in India by Mohanram et al. (1974) who were able to show that the activity of lysozyme in leucocytes was significantly lower in children with ocular signs of vitamin A deficiency compared with control children. Following vitamin A therapy, the levels of enzyme in the deficient children were restored to normal.

\section{HOST-RESISTANCE: LYMPHOID ORGANS AND BLOOD LYMPHOCYTES}

The immune system comprises a number of organs and cell-types which have evolved to recognize accurately and specifically non-self antigens such as those present on microbes and microbe-infected cells which results ultimately in elimination of such microbes or cells. In the early work of Bang et al. (1973) using a chicken-Newcastle disease virus model, vitamin A deficiency or Newcastle disease virus infection alone were found to have only moderate effects on lymphoid systems. However, together they caused substantial or even total loss of lymphocytes from primary lymphoid organs which was accompanied by rapid loss of body-weight. Using our model, in which there was no loss of body-weight (Sijtsma et al. 1991b), we could demonstrate that vitamin A deficiency resulted in lower weights of the bursa of Fabricius in both non-infected and infected chickens and of thymus in infected chickens, indicating changes in production or recruitment, or both, of B- and T-cells respectively (Table 3). However, no effect of vitamin A deficiency on spleen weight was observed. Other authors have found similar results with regard to weight of bursa and spleen in vitamin A-deficient chickens (Panda \& Combs, 1963; Davis \& Sell, 1983). Weight of thymus appears to be affected more when vitamin A deficiency is severe enough to reduce feed intake and, thus, precipitate protein-energy malnutrition both in chickens (Bang et al. 1972; Davis \& Sell, 1983) and rats (Krishnan et al. 1974) but normal in vitamin A-deficient chickens (Panda \& Combs, 1963; Davis \& Sell, 1983), rats (Chandra \& Au, 1981; Mark et al. 1981) and mice (Ahmed et al. 1990) without protein-energy malnutrition. This is in accordance with our observation showing the lowest absolute and relative weight of thymus in vitamin 
Table 4. Vitamin A deficiency and Newcastle disease virus (NDV) infection in chickens: effect on numbers of peripheral blood lymphocytes 5 and 11 d after infection

(Values are means with their standard errors for ten to twelve birds per group)

\begin{tabular}{|c|c|c|c|c|}
\hline & \multicolumn{4}{|c|}{ No. of lymphocytes $\left(\times 10^{7} / \mathrm{ml}\right)$} \\
\hline & \multicolumn{2}{|c|}{$5 \mathrm{~d}$} & \multicolumn{2}{|c|}{$11 \mathrm{~d}$} \\
\hline & Mean & $\mathrm{SE}$ & Mean & SE \\
\hline \multicolumn{5}{|l|}{ Non-infected chickens } \\
\hline Vitamin $\mathrm{A}$-adequate & $1.7^{\mathrm{a}}$ & $0 \cdot 1$ & $1 \cdot 8^{\mathrm{a}}$ & $0 \cdot 2$ \\
\hline Vitamin A-deficient & $1 \cdot 3^{b}$ & $0 \cdot 3$ & $1 \cdot 2^{\mathrm{b}}$ & $0 \cdot 1$ \\
\hline \multicolumn{5}{|l|}{ NDV-infected chickens } \\
\hline Vitamin A-adequate & $1 \cdot 3^{\mathrm{b}}$ & $0 \cdot 1$ & $2 \cdot 1^{c}$ & $0 \cdot 1$ \\
\hline Vitamin A-deficient & $1 \cdot 0^{\mathrm{c}}$ & $0 \cdot 1$ & $1 \cdot 5^{\mathrm{d}}$ & $0 \cdot 1$ \\
\hline
\end{tabular}

a,b,c,d Values in a column with unlike superscript letters were significantly different (Tukey): $P<0 \cdot 05$.

A-deficient chickens infected with Newcastle disease virus, which also tended to grow more slowly.

The changes in weight of lymphoid organs observed in our experiment were accompanied by changes in the number of circulating lymphocytes (Sijtsma et al. 1991b). Vitamin A deficiency resulted in a significant lymphopaenia which was even more pronounced in Newcastle disease virus-infected chickens during the acute phase of infection (Table 4). Lymphopaenia has been described by other authors in vitamin A deficiency (Bang et al. 1972, 1973; Nauss et al. 1979; Davis \& Sell, 1983) and Newcastle disease virus infection (Smith \& Sweet, 1984; Dhir et al. 1986). Lymphopaenia induced by vitamin $A$ deficiency might be attributed to impaired development of primary lymphoid organs, as indicated by the reduced weight of the bursa of Fabricius with consequent impaired proliferation and differentiation of lymphoid cells. It could also be due to changes in homing patterns (McDermott et al. 1982; Takagi \& Nakano, 1983). The increase in the number of circulating peripheral blood lymphocytes following the period of Newcastle disease virus-induced lymphopaenia might be attributed to a change in migration pattern (Woodruff \& Woodruff, 1975; Smith et al. 1987) rather than increased production of new lymphocytes (Smith \& Sweet, 1984). Both the lymphopaenic effect and the subsequent increase in the number of circulating lymphocytes due to Newcastle disease virus infection were less pronounced in vitamin A-deficient chickens than in their counterparts pair-fed the control diet. This may suggest that the recruitment of cells has been impaired. The results from the present study indicate that vitamin A deficiency affects lymphoid cell systems and that this is aggravated by concomitant Newcastle disease virus infection.

Using flow cytometry with a monoclonal antibody specific for chicken immunoglobulin (Ig) light chain, we have been able to characterize the circulating lymphocyte population into surface Ig-positive cells (B-cells) and surface Ig-negative cells (mainly T-cells). As shown in Table 5, vitamin A deficiency significantly lowered the number of circulating B-cells and, in Newcastle disease virus-infected chickens, the number of T-cells (Rombout, 1991). These changes in the numbers of B-and T-cells are in line with the changes in the weights of the bursa of Fabricius and thymus respectively. An increase in 
Table 5. Vitamin A deficiency and Newcastle disease virus (NDV) infection in chickens: effect on numbers of peripheral blood lymphocyte sub-populations $9 \mathrm{~d}$ after infection (flow cyctometric analysis)

(Values are means with their standard errors for five birds per group)

\begin{tabular}{|c|c|c|c|c|}
\hline & \multicolumn{4}{|c|}{ No. of lymphocytes $\left(\times 10^{7} / \mathrm{ml}\right)$} \\
\hline & \multicolumn{2}{|c|}{$\begin{array}{c}\text { Surface Ig }+ \\
\text { (B-cells) }\end{array}$} & \multicolumn{2}{|c|}{$\begin{array}{c}\text { Surface Ig- } \\
\text { (mainly T-cells) }\end{array}$} \\
\hline & Mean & SE & Mean & $\mathrm{SE}$ \\
\hline \multicolumn{5}{|l|}{ Non-infected chickens } \\
\hline Vitamin A-adequate & $0 \cdot 39^{\mathrm{a}}$ & 0.07 & $1 \cdot 46^{\mathrm{ab}}$ & $0 \cdot 18$ \\
\hline Vitamin A-deficient & $0 \cdot 18^{\mathrm{b}}$ & 0.03 & $1.05^{\mathrm{a}}$ & $0 \cdot 35$ \\
\hline \multicolumn{5}{|l|}{ NDV-infected chickens } \\
\hline Vitamin A-adequate & $0 \cdot 31^{2}$ & 0.06 & $1.92^{\mathrm{b}}$ & $0 \cdot 31$ \\
\hline Vitamin A-deficient & $0 \cdot 22^{\mathrm{b}}$ & $0 \cdot 06$ & $1 \cdot 34^{\mathrm{a}}$ & $0 \cdot 29$ \\
\hline
\end{tabular}

a b Values in a column with unlike superscript letters were significantly different (Tukey): $P<0 \cdot 05$.

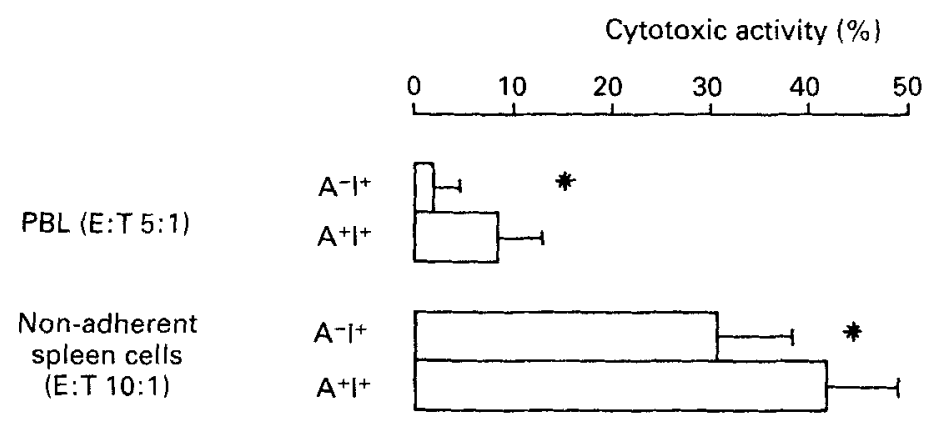

Fig. 2. Effect of vitamin A deficiency on cytotoxic activity of in vivo Newcastle disease virus (NDV)-reinfected peripheral blood lymphocytes (PBL) and non-adherent spleen cells (effector (E) cells) on in vitro Newcastle disease virus-infected spleen (target; T) cells. Values are means and 1 SD represented by horizontal bars for five chickens per group. $\mathrm{A}^{-}$, vitamin $\mathrm{A}$-deficient; $\mathrm{A}^{+}$, vitamin $\mathrm{A}$-adequate; $\mathrm{I}^{+}$, cells are derived from NDV-infected chickens. "Mean values were significantly different from those for $\mathrm{A}^{+} \mathrm{I}^{+}$(Student's $t$ test): $P<0.05$.

the number of B-cells in spleen and lymph node has been observed in vitamin A-deficient mice (Smith et al. 1987), while a decreased number of B-cells has been found in spleens of vitamin A-deficient rats which also suffered from protein-energy malnutrition (Nauss et al. 1979). Newcastle disease virus infection did not significantly increase the number of circulating B- or T-cells at the moment of measurement.

\section{HOST-RESISTANCE: SYSTEMIC CELL-MEDIATED IMMUNITY}

Depressed cellular response to mitogens in vitamin A deficiency has been reported in rats (Nauss et al. 1979) and chickens (Davis \& Sell, 1983; Friedman \& Sklan, 1989). We have shown (Fig. 2) that vitamin A deficiency reduces cytotoxic T-lymphocyte activity to Newcastle disease virus infection (Sijtsma et al. 1990). This impairment in an important part of the cell-mediated defence system could have important implications for recovery 
from viral infection. In studies in children with marginal vitamin A deficiency, no difference in in vitro mitogenic stimulation of T-cells has been found (Bhaskaram \& Reddy, 1975; Bhaskaram et al. 1989a) but as mentioned previously, there may have been no true differences in vitamin A status between the groups studied.

\section{HOST-RESISTANCE: SYSTEMIC HUMORAL IMMUNITY}

Vitamin A deficiency has been shown to be accompanied by low levels of immunoglobulin in pigs (Harmon et al. 1963), rats (Sirinsha et al. 1980) and chickens (Friedman \& Sklan, 1989), impaired IgG response in mice (Barnett, 1983; Smith \& Hayes, 1987) and chickens (Friedman \& Sklan, 1989), and impaired IgA response in rats (Sirinsha et al. 1980). Increased levels of immunoglobulin have also been reported (Davis \& Sell, 1983; Gershwin et al. 1984). We have studied primary and secondary immunization with antigens differing in thymus dependency (see Sijtsma, 1989): sheep erythrocytes and bovine serum albumin as thymus-dependent antigens and Brucella abortus as a more or less thymus-independent antigen during and after the acute phase of disease produced by Newcastle disease virus infection. Vitamin A deficiency did not affect the hemagglutination-inhibition antibody response to Newcastle disease virus. The level of the primary and secondary IgG response to bovine serum albumin and of the primary IgG response to sheep erythrocytes and bovine serum albumin was reduced, while the secondary IgM response to sheep erythrocytes and Brucella abortus was slightly elevated by vitamin A deficiency. Newcastle disease virus infection reduced primary IgM and IgG responses to sheep erythrocytes and bovine serum albumin but not to Brucella abortus, indicating a defect in $\mathrm{T}$-helper cell function as has been suggested earlier (Wisniewski et al. 1982). The combination of vitamin A deficiency and Newcastle disease virus infection resulted in the lowest IgG titres to thymus-dependent antigens. As most pathogens are of the latter type, the risk for secondary infection would appear to be increased in vitamin A deficiency and Newcastle disease virus infection.

\section{HOST RESISTANCE: MUCOSAL IMMUNITY}

The basic component of immunological protection at mucosal surfaces is secretory immunoglobulin A (sIgA). In our model, vitamin A deficiency lowered the concentration of sIgA in bile and this effect was even more pronounced in chickens also infected with Newcastle disease virus (see Sijtsma, 1989). However, there was no effect on the IgM concentration in bile or on the number of IgA- or IgM-containing plasma cells in mucosal cells indicating that hepatobiliary transport of sIgA is impaired in vitamin A deficiency and that this effect is exacerbated by Newcastle disease virus infection. Similar results have been found in non-infected vitamin A-deficient rats (Puengtomwatanakul \& Sirisinha, 1986). Thus, the host's ability to defend itself at the mucosal level against both primary and secondary infections would be impaired.

\section{CONCLUDING REMARKS}

In vitamin A deficiency, many aspects of the non-specific and specific host defence mechanisms would appear, at least in experimental animals, to be affected. However, the mechanisms involved are still poorly understood. It is likely that impairment of the 
synthesis of glycoproteins will be shown to play a crucial role since they are essential components of receptors and may be involved in the regulation of gene expression (Wolf, 1984). At this stage, studies in humans have not shown consistent impairment of acquired immunity. While the animals used in experimental studies have often displayed symptoms of not only severe vitamin A deficiency but also of protein-energy malnutrition, many of the studies in humans have probably not assessed vitamin A status adequately. Serum retinol levels do not discriminate between normal and marginal vitamin A status satisfactorily. Thus, future studies on immune competence in humans should assess vitamin A status using methods which estimate body stores such as the relative dose-response method (Campos et al. 1987) or changes in structure or function such as conjunctival impression cytology (Wittpenn et al. 1986).

\section{REFERENCES}

Ahmed, F., Jones, B. D. \& Jackson, A. A. (1990). The interaction of vitamin A deficiency and rotavirus infection in the mouse. British Journal of Nutrition 63, 363-373.

Anonymous (1987). Vitamin A supplementation. Nutrition Reviews 45, 48-50.

Bang, B. G., Foard, M. \& Bang, F. B. (1973). The effect of vitamin A deficiency and Newcastle disease on lymphoid cell systems in chickens. Proceedings of the Society of Experimental Biology and Medicine 143, $1140-1146$.

Bang, F. B., Bang, B. G. \& Foard, M. (1972). Lymphocyte depression induced in chickens on diets deficient in vitamin A and other components. American Journal of Pathology 68, 147-162.

Bang, F. B., Bang, B. G. \& Foard, M. (1975). Acute Newcastle disease virus infection of the upper respiratory tract of the chicken. II. The effect of diets deficient in vitamin $A$ on the pathogenesis of the infection. American Journal of Pathology 79, 417-424.

Barnett, J. B. (1983). Immunomodulating effects of 13-cis retinoic acid on the $\operatorname{IgG}$ and IgM responses of $\mathrm{BALB} / \mathrm{c}$ mice. International Archives of Allergy and Applied Immunology 72, 227-233.

Bendich, A. (1991). $\beta$-carotene and the immune response. Proceedings of the Nutrition Society 50, 263-274.

Bhaskaram, P., Juothi, S. A., Rao, K. V. \& Rao, B. S. N. (1989a). Effects of subclinical vitamin A deficiency and administration of vitamin $\mathrm{A}$ as a single large dose of immune function in children. Nutrition Research $\mathbf{9}$, $1017-1025$.

Bhaskaram, P., Sharada, K., Sivakumar, B., Rao, K. V. \& Nair, M. (1989b). Effect of iron and vitamin A deficiences on macrophage function in children. Nutrition Research 9, 35-45.

Bhaskaram, P. \& Reddy, V. (1975). Cell mediated immunity in iron and vitamin deficient children. British Medical Journal 3, 522.

Campos, A. C. S., Flores, H. \& Underwood, B. A. (1987). Effect of an infection on vitamin A status of children as measured by the relative dose response (RDR). American Journal of Clinical Nutrition 46, 91-94.

Chandra, R. K. \& Au, B. (1981). Single nutrient deficiency and cell-mediated immune responses. III. Vitamin A. Nutrition Research 1, 181-185.

Cohen, B. E. \& Elin, R. J. (1974). Vitamin A-induced nonspecific resistance to infection. Journal of Infectious Diseases 129, 597-600.

Darip, M. D., Sirisinha, S. \& Lamb, A. (1979). Effect of vitamin A deficiency on the susceptibility of rats to Angiostrongylus cantonensis. Proceedings of the Society of Experimental Biology and Medicine 161, $600-604$.

Davis, C. Y. \& Sell, J. L. (1983). Effect of all-trans retinol and retinoic acid nutriture on the immune system of chicks. Journal of Nutrition 113, 1914-1919.

Davis, C. Y. \& Sell, J. L. (1989). Immunoglobulin concentrations in serum and tissues of vitamin A-deficient broiler chicks after Newcastle disease virus vaccination. Poultry Science 68, 136-144.

Dhir, R. C., Garg, U. K., Chabra, I. S. \& Datta, I. C. (1986). Studies on hematological and biochemical parameters in chickens after infection with Newcastle disease virus of varying virulence. Indian Journal of Poultry Science 21, 322-325.

Friedman, A. \& Sklan, D. (1989). Antigen-specific immune response impairment in the chick as influenced by dietary vitamin A. Journal of Nutrition 119, 790-795. 
Gershwin, M. E., Lentz, D. R., Beach, R. S. \& Hurley, L. S. (1984). Nutritional factors and autoimmunity. IV. Dietary vitamin A deficiency induces a selective increase in IgM autoantibodies and hypergammaglobulinaemia in New Zealand Black mice. Journal of Immunology 133, 222-226.

Gopalan, C. (1986). Vitamin A deficiency and childhood mortality. NFI Bulletin 7, 6-7.

Green, H. N. \& Mellanby, E. (1928). Vitamin A as an anti-infective agent. British Medical Journal 2, 691-696.

Harmon, B. G., Miller, E. R., Hoefer, J. A., Ullrey, D. E. \& Luecke, R. W. (1963). Relationship of specific nutrient deficiencies to antibody production in swine. I. Vitamin A. Journal of Nutrition 79, 263-268.

Hatchell, D. I. \& Sommer, A. (1984). Detection of ocular surface abnormalities in experimental vitamin A deficiency. Archives of Ophthalmology 104, 237-239.

Inua, M., Duggan, M. B., West, C. E., Whittle, H. C., Sandford-Smith, H. C. \& Glover, J. (1983). Post-measles corneal ulceration in children in northern Nigeria: the role of vitamin A, malnutrition and measles. Annals of Tropical Paediatrics 3, 181-191.

Kornfield, R. \&. Kornfield, S. (1980). Structure of glycoproteins and their oligosaccharide units. In The Biochemistry of Glycoproteins and Proteoglycans, pp. 1-33 [S. Lennarz, editor]. New York: Plenum.

Krishnan, S., Bhuyan, U. N., Talwar, G. P. \& Ramalingaswami, V. (1974). Effect of vitamin A and protein-calorie undernutrition on immune responses. Immunology 27, 383-392.

Krishnan, S., Krishnan, A. D., Mustapha, A. S., Talwar, G. P. \& Ramalingaswami, V. (1976). Effect of vitamin $\mathrm{A}$ and undernutrition on the susceptibility of rodents to a malarial parasite Plasmodium berghei. Journal of Nutrition 106, 784-791.

McDermott, M. R., Mark, D. A., Befus, A. D., Baliga, B. S., Suskind, R. M. \& Bienenstock, J. (1982). Impaired intestinal localization of mesenteric lymphoblasts associated with vitamin A deficiency and protein-calorie malnutrition. Immunology 45, 1-5.

Mark, D. A., Nauss, K. M., Baliga, B. S. \& Suskind, R. M. (1981). Depressed transformation response by splenic lymphocytes from vitamin A-deficient rats. Nutrition Research 1, 489-497.

Milton, R. C., Reddy, V. \& Naidu, A. N. (1987). Mild vitamin deficiency and childhood morbidity: an Indian experience. American Journal of Clinical Nutrition 46, 827-829.

Mogensen, S. C. (1979). Role of macrophages in natural resistance to virus infections. Microbiological Reviews $43,1-26$.

Mohanram, M., Reddy, V. \& Mishra, S. (1974). Lysozyme activity in plasma and leucocytes in malnourished children. British Medical Journal 32, 313-316.

Moore, T. (1957). Vitamin A. Amsterdam: Elsevier.

Nauss, K. M., Anderson, C. A., Connor, M. W. \& Newberne, P. M. (1985). Ocular infection with herpes simplex virus (HSV-1) in vitamin A-deficient and control rats. Journal of Nutrition 115, 1300-1315.

Nauss, K. M., Mark, D. A. \& Suskind, R. M. (1979). The effect of vitamin A deficiency on the in vitro cellular immune response of rats. Journal of Nutrition 109, 1815-1823.

Nauss, K. M. \& Newberne, P. M. (1985). Local and regional immune function of vitamin A-deficient rats with ocular herpes simplex virus (HSV-1) infection. Journal of Nutrition 115, 1316-1324.

Omori, M. \& Chytil, F. (1982). Mechanisms of vitamin A action: gene expression in retinol deficient rats. Journal of Biological Chemistry 257, 14370-14374.

Ongsakul, M., Sirisinha, S. \& Lamb, A. J. (1985). Impaired blood clearance of bacteria and phagocytic activity in vitamin A-deficient rats. Proceedings of the Society of Experimental Biology and Medicine 178, 204-208.

Oomen, H. A. P. C., McLaren, D. S. \& Escapini, H. (1964). Epidemiology and public health aspects of hypovitaminosis A: a global survey on xerophthalmia. Tropical and Geographical Medicine 16, 271-315.

Panda, B. \& Combs, G. F. (1963). Impaired antibody production in chicks fed diets low in vitamin A, pantothenic acid or riboflavin. Proceedings of the Society of Experimental Biology and Medicine 113, 530-534.

Pepping, F., van der Giezen, A. M., de Jonge, K. I. \& West, C. E. (1989). Food composition of children with and without xerophthalmia in rural Tanzania. Tropical and Geographical Medicine 41, 14-21.

Peto, R., Doll, R., Buckley, J. D. \& Sporn, M. B. (1981). Can dietary $\beta$-carotene materially reduce human cancer rates? Nature 290, 201-208.

Puengtomwatanakul, S. \& Sirisinha, S. (1986). Impaired biliary secretion of immunogiobulin A in vitamin A-deficient rats. Proceedings of the Society of Experimental Biology and Medicine 182, 437-442.

Rombout, J. H. W. M., van Rens, B. T. T. M., Sijtsma, S. R., van der Weide, M. C. \& West, C. E. (1991). Effects of vitamin A deficiency and Newcastle disease virus infection on lymphocyte subpopulations in chicken blood. Veterinary Immunology and Immunopathology 27 (In the Press).

Scrimshaw, N. S., Taylor, C. E. \& Gordon, J. E. (1968). Interactions of Nutrition and Infection. WHO Monograph series no. 57, Geneva: WHO. 
Shenai, J. P., Kennedy, K. A., Chytil, F. \& Stahlman, M. T. (1987). Clinical trial of vitamin A supplementation in infants susceptible to bronchopulmonary dysplasia. Journal of Pediatrics 111, 269-277.

Sijtsma, S. R. (1989). Vitamin A deficiency and Newcastle disease virus infection in chickens: a model for the study of measles infection in vitamin A-deficient children. $\mathrm{PhD}$ Thesis (Proefschrift), Wageningen Agricultural University.

Sijtsma, S. R., Rombout, J. H. W. M., Dohmen, M. J. W., West, C. E. \& van der Zijpp, A. J. (1991a). Effect of vitamin A deficiency on the activity of macrophages in Newcastle disease virus-infected chickens. Veterinary Immunology and Immunopathology 27, 17-27.

Sijtsma, S. R., Rombout, J. H. W. M., Kiepurski, A. K., West, C. E. \& van der Zijpp, A. J. (1991b). Changes in lymphoid organs and blood lymphocytes induced by vitamin A deficiency and Newcastle disease virus infection. Developmental and Comparative Immunology (In the Press).

Sijtsma, S. R., Rombout, J. H. W. M., van der Zijpp, A. J. \& West, C. E. (1990). Vitamin A deficiency impairs cytotoxic $\mathrm{T}$ lymphocyte activity in Newcastle disease virus-infected chickens. Veterinary Immunology and Immunopathology 26, 191-201.

Sijtsma, S. R., West, C. E., Rombout, J. H. W. M. \& van der Zijpp, A. J. (1989a). The interaction between vitamin A status and Newcastle disease virus infection in chickens. Journal of Nutrition 119, 932-939.

Sijtsma, S. R., West, C. E., Rombout, J. H. W. M. \& van der Zijpp, A. J. (1989b). Effect of Newcastle disease virus infection on vitamin A metabolism in chickens. Journal of Nutrition 119, 940-947.

Sirinsha, S., Darip, M. D., Moonkarndi, P., Ongsakul, M. \& Lamb, A. J. (1980). Impaired local immune response in vitamin A-deficient rats. Clinical and Experimental Immunology 40, 127-135.

Smith, S. M. \& Hayes, C. E. (1987). Contrasting impairments in IgM and IgG responses of vitamin A-deficient mice. Proceedings of the National Academy of Sciences USA 84, 5878-5882.

Smith, S. M., Levy, N. S. \& Hayes, C. E. (1987). Impaired immunity in vitamin A-deficient mice. Journal of Nutrition $117,857-858$.

Smith, H. \& Sweet, C. (1984). The pathogenicity of viruses. In Topley and Wilson's Principles of Bacteriology, Virology and Immunity, 7th ed., vol. 4, pp. 94-123 [F. Brown and G. Wilson, editors]. London: Edward Arnold Publishers Limited.

Sommer, A., Katz, J. \& Tarwotjo, I. (1984). Increased risk of respiratory disease and diarrhoea in children with preexisting mild vitamin A deficiency. American Journal of Clinical Nutrition 40, 1090-1095.

Sommer, A., Tarwotjo, I., Djunaedini, E., West, K. P., Loerden, A. A. \& Tilden, R. (1986). Impact of vitamin A supplementation on childhood mortality. Lancet $\mathbf{i}, 1169-1173$.

Sommer, A., Tarwotjo, I., Hussaini, G. \& Susanto, D. (1983). Increased mortality in children with mild vitamin A deficiency. Lancet ii, 585-588.

Sommer, A., Tarwotjo, I. \& Katz, J. (1987). Increased risk of xerophthalmia following diarrhoea and respiratory disease. American Journal of Clinical Nutrition 45, 977-980.

Squibb, R. L. \& Veros, H. (1961). Avian disease virus and nutrition relationships. I. Effect of vitamin A on growth, symptoms, mortality and vitamin A reserves of white Leghorn chicks infected with Newcastle disease virus. Poultry Science 40, 425-433.

Stiggelbout, A. M., van der Giezen, A. M., Blauw, Y. H., Blok, E., van Staveren, W. A. \& West, C. E. (1989). Development and relative validity of a food frequency questionnaire for the estimation of intake of retinol and $\beta$-carotene. Nutrition and Cancer 12, 289-299.

Takagi, H. \& Nakano, K. (1983). The effect of vitamin A depletion on antigen-stimulated trapping of peripheral lymphocytes in local lymph nodes of the rat. Immunology 48, 123-128.

Wisniewski, J., Grabowska, G. \& Wasielewska, A. (1982). Immunosuppressive action of the La Sota strain of Newcastle disease virus. Medycyna Weterynaryjna 38, 41-46.

Wittpenn, J, Tseng, S. \& Sommer, A. (1986). Detection of early xerophthalmia by impression cytology. Archives of Ophthalmology 104, 237-239.

Wolbach, S. B. \& Howe, P. R. (1925). Tissue changes following deprivation of fat-soluble vitamin. Journal of Experimental Medicine 42, 753-757.

Wolf, G. (1984). Multiple functions of vitamin A. Physiological Reviews 64, 873-937.

Woodruff, J. F. \& Woodruff, J. J. (1975), Viral Immunology and Immunopathology. London: Academic Press. 